\title{
MEMBANGUN KARAKTER ANAK DENGAN BUDAYA KEARIFAN LOKAL DALAM PROSES PEMBELAJARAN DI SEKOLAH
}

\author{
Sudarmiani \\ Dosen Prodi Pendidikan Ekonomi IKIP PGRI Madiun \\ Mahasiswa S3 Ilmu Pendidikan
}

\begin{abstract}
In the current era of globalization, the challenges before us as a nation is the ability to put the strength of character as a nation.Therefore, the implementation of policy and character-based education in schools is very important and strategic in order to build this nation. Local knowledge can serveas a source of values for then oble purpose. In other words, local knowledge can be a well that never dry as the source of values for the realization of policy goals nation.In addition to functioning as a filter for the values that come from outside, local wisdom can also be used to increase motivation, perseverance, tolerance, and reduce flare-ups that are internal.

Build the character of students to do during the learning process takes place. In each of the learning process we can always tuck load the values of honesty, courage, perseverance and tenacity, confident attitude, diligent study and work, respect for teachers, respect and care for the others, life is tough does not know the word surrender and positive attitude other. Some wise words that are part of the local wisdom can be used as the basis to develop character values in the learning process. Wise sentence can be used to motivate the students to build a positive attitude.
\end{abstract}

Keywords: Build the character, indigenous culture

\section{A. Pendahuluan}

Pembangunan karakter dan jati diri bangsa merupakan cita-cita luhur yang harus diwujudkan melalui penyelenggaraan pendidikan yang terarah dan berkelanjutan. Pendidikan karakter saat ini memang menjadi isu utama pendidikan, selain menjadi bagian dari proses pembentukan akhlak anak bangsa, pendidikan karakter juga diharapkan mampu menjadi pondasi utama dalam mensukseskan Indonesia Emas 2025.

Penanaman nilai-nilai akhlak, moral, dan budi pekerti seperti tertuang dalam Undang- undang Republik Indonesia Nomor 20 Tahun 2003 tentang Sistem Pendidikan Nasional harus menjadi dasar pijakan utama dalam mendesain, melaksanakan, dan mengevaluasi sistem pendidikan nasional. Dalam UU No. 20 Tahun 2003 Tentang Sistem Pendidikan Nasional pada Pasal 3, menyebutkan bahwa pendidikan nasional berfungsi mengembangkan kemampuan 
dan membentuk karakter serta peradaban bangsa yang bermartabat dalam rangka mencerdaskan kehidupan bangsa.Pendidikan nasional bertujuan untuk berkembangnya potensi peserta didik agar menjadi manusia yang beriman dan bertakwa kepada Tuhan Yang Maha Esa, berakhlak mulia, sehat, berilmu, cakap, kreatif, mandiri, dan menjadi warga negara yang demokratis serta bertanggung jawab.

Pendidikan bukan hanya membangun kecerdasan dan transfer of knowledge, tetapi juga harus mampu membangun karakter atau character building dan perilaku. Dengan hakekat pendidikan dan dibangun metodologi yang tepat, maka diharapkan dapat dibangun intellectual curiosity dan membangun common sense. Tidak bisa ditunda lagi, generasi penerus bangsa harus serius untuk dibekali pendidikan karakter agar dapat memenuhi 5 nilai manusia unggul seperti disampaikan oleh Presiden SBY pada acara Puncak Peringatan Hari Pendidikan Nasional dan Hari Kebangkitan Nasional 2011, Jumat 20 Mei 2011 yaitu :

1. Manusia Indonesia yang bermoral, berakhlak dan berperilaku baik;

2. Mencapai masyarakat yang cerdas dan rasional;

3. Manusia Indonesia ke depan menjadi manusia yang inovatif dan terus mengejar kemajuan;

4. Memperkuat semangat "Harus Bisa", yang terus mencari solusi dalam setiap kesulitan;

5. Manusia Indonesia haruslah menjadi patriot sejati yang mencintai bangsa, Negara dan tanah airnya.

Perkembangan ilmu dan teknologi di era globalisasi sangat mempengaruhi perilaku anak bangsa yang semakin membuat hilangnya nilainilai karakter bangsa. Hilangnya nilai-nilai karakter bangsa ini tidak hanya di pengaruhi oleh perkembangan ilmu dan teknologi saat ini, akan tetapi juga dipengaruhi oleh lingkungan sekitar para generasi muda. Berbagai permasalahan yang ada di Indonesia saat ini sudah sangat mencerminkan hilangnya nilainilai karakter bangsa misalnya banyaknya korupsi di berbagai lembaga untuk memperkaya diri sendiri, mafia kasus sampai masalah rendahnya kedisiplinan di berbagai lembaga. 
Hilangnya nilai-nilai karakter bangsa saat ini salah satunya juga dipengaruhi oleh sistem pendidikan yang diberlakukan, dengan adanya sistem kelulusan yang hanya mengejar nilai dan lulus. Untuk mencapai hal tersebut beberapa siswa tidak lagi mempercayai kemampuan dirinya sehingga mereka berusaha berlaku tidak jujur dengan membeli kunci jawaban atau mencotek. Hal itu tidak hanya dilakukan oleh siswa saja akan tetapi beberapa pendidik memberikan jawaban kepada siswanya supaya sekolahnya mendapatkan peringkat terbaik dan siswanya lulus $100 \%$. Tentunya kita masih ingat juga tentang kejadian di Jawa Timur di mana kepala sekolah mengancam salah satu siswa saat ujian nasional supaya memberitahukan jawaban kepada teman-teman yang lain, jika tidak maka tidak akan diluluskan. Berbagai kejadian di atas terdeteksi bahwa nilai kejujuran, rasa percaya diri, nilai sportivitas, menghormati hak orang lain, kerja keras dll sebagai nilai karakter bangsa mulai tidak dipedulikan lagi baik oleh pendidik maupun siswa.

Munculnya berbagai permasalahan tersebut kita tidak dapat menyalahkan kepada salah satu pihak saja dan siapa yang harus bertanggung jawab terhadap semua ini, akan tetapi permasalah tersebut menjadi masalah seluruh warga Negara Indonesia. Maka dari itu untuk menumbuhkan nilai-nilai karakter bangsa yang telah hilang, kita sebagai pendidik harus dapat menanamkan kembali nilai-nilai karakter bangsa di lingkungan sekolah, terutama sekali melalui proses pembelajaran.

\section{B. Pembahasan}

\section{Pendidikan Karakter}

Pendidikan karakter merupakan sebuah istilah yang semakin hari semakin mendapatkan pengakuan dari masyarakat Indonesia. Hal ini akan semakin tampak dengan dirasakannya berbagai ketimpangan hasil pendidikan dilihat dari perilaku lulusan pendidikan formal saat ini, dengan banyaknya perilaku yang bertentangan dengan nilai- nilai etika dan norma yang berlaku, misalnya; korupsi, maraknya seks bebas di kalangan remaja, pemakaian narkoba, tawuran antar pelajar, pembunuhan, dan perampokan.

Istilah pendidikan karakter berasal dari dua kata, yakni kata pendidikan 
dan karakter. Menurut Undang-Undang Sistem Pendidikan Nasional, pendidikan adalah usaha sadar dan terencana untuk mewujudkan suasana belajar dan proses pembelajaran agar peserta didik secara aktif mengembangkan potensi dirinya untuk memiliki kekuatan spiritual keagamaan, pengendalian diri, kepribadian, kecerdasan, akhlak mulia, serta keterampilan yang diperlukan dirinya, masyarakat, bangsa, dan negara (Pasal I ayat (1) Undang-Undang Nomor 20 Tahun 2003).

Definisi lain dikemukakan o1eh Gaffar (2011,5), pendidikan karakter adalah sebuah proses transformasi nilai-nilai kehidupan untuk ditumbuh kembangkan dalam kepribadian seseorang sehingga menjadi satu dalam perilaku kehidupan orang itu." Dalam definisi tersebut terdapat tiga pikiran penting yakni 1) proses transformasi nilai, 2) ditumbuh kembangkan dalam kepribadian, 3) menjadi satu dalam perilaku.

Pendapat lain dikemukakan oleh Dharma Kesuma dkk. (2011,23), bahwa pendidikan karakter dalam seting sekolah sebagai "pembelajaran yang mengarah pada penguasaan dan pengembangan perilaku anak secara utuh yang didasarkan pada suatu nilai tertentu yang dirujuk oleh sekolah."

Menurut Hurlock $(1974,8)$, secara tidak langsung mengungkapkan bahwa karakter terdapat pada kepribadian. Karakter mengimplikasikan sebuah standar moral dan melibatkan sebuah pertimbangan nilai. Karakter berkaitan dengan tingkah laku yang diatur oleh upaya dan keinginan. Hati nurani, sebuah unsur esensial dari karakter, adalah sebuah pola kebiasaan yang mengontrol tingkah laku seseorang, membuatnya selaras dengan pola-pola kelompok yang diterima secara sosial. Definisi karakter dari Hurlock, sementara ini dapat digunakan untuk menganalisis secara lebih jauh tentang karakter dan implikasinya.

Dari mana memulai dibelajarkannya nilai-nilai karakter bangsa, dari pendidikan informal, dan secara pararel berlanjut pada pendidikan formal dan nonformal. Tantangan saat ini dan ke depan bagaimana kita mampu menempatkan pendidikan karakter sebagai suatu kekuatan bangsa. Oleh karena itu kebijakan dan implementasi pendidikan yang berbasis karakter 
menjadi sangat penting dan strategis dalam rangka membangun bangsa ini. Hal ini tentunya juga menuntut adanya dukungan yang kondusif dari pranata politik, sosial, dan budaya bangsa.

\section{Fungsi dan Tujuan Pendidikan Karakter}

\section{a. Fungsi Pendidikan Karakter}

Pada hakikatnya, tujuan pendidikan nasional tidak boleh melupakan landasan konseptual filosofi pendidikan yang mampu menyiapkan generasi masa depan untuk dapat bertahan hidup (survive) dan berhasil menghadapi tantangan-tantangan zamannya. Fungsi dan tujuan pendidikan nasional menurut Undang-Undang Sistem Pendidikan Nasional Tahun 2003 Bab 2 Pasal 3 adalah sebagai berikut."Pendidikan nasional berfungsi mengembangkan kemampuan dan membentuk watak serta peradaban bangsa yang bermartabat dalam rangka mencerdaskan kehidupan bangsa, bertujuan untuk mengembangkan potensi peserta didik agar menjadi manusia yang beriman dan bertaqwa kepada Tuhan Yang Maha Esa, berakhlak mulia, sehat, berilmu, cakap, kreatif, mandiri, dan menjadi warga negara yang demokratis serta bertanggung jawab (Undang-Undang No. 20 Tahun 2003).

Mencernati fungsi pendidikan nasional, yakni mengembangkan kemampuan dan membentuk watak serta peradaban bangsa seharusnya memberikan pencerahan yang memadai bahwa pendidikan harus berdampak pada watak manusia atau bangsa Indonesia. Fungsi ini amat berat untuk dipikul dan dilaksanakan terutama apabila dikaitkan dengan siapa yang bertanggung jawab untuk keberlangsungan fungsi ini.

Fungsi pertama "mengembangkan kemampuan" dapat dipahami bahwa pendidikan nasional menganut aliran konstruktivisme, yang mempercayai bahwa peserta didik adalah manusia yang potensial dan dapat dikembangkan secara optimal melalui proses pendidikan. Setiap layanan pendidikan yang ada di Indonesia harus dipersepsi bahwa peserta didik itu memiliki potensi yang luar biasa dan perlu difasilitasi melalui proses pendidikan untuk mengembangkan potensinya. 
Fungsi kedua pendidikan nasional adalah "membentuk watak" mengandung makna bahwa pendidikan nasional harus diarahkan pada pembentukan watak. Pendidikan yang berorientasi pada watak peserta didik merupakan suatu hal yang tepat, tetapi perlu diperjelas mengenai istilah perlakuan terhadap "watak" Apakah watak itu harus "dikembangkan", "dibentuk" atau "difasilitasi” Perspektif pedagogik, lebih memandang bahwa pendidikan itu mengembangkan, menguatkan, memfasilitasi watak, bukan membentuk watak. Jika watak dibentuk, maka tidak ada proses pedagogik/pendidikan, yang terjadi adalah pengajaran (Kesuma, dkk., 2011: 7).

Secara garis besar fungsi pendidikan karakter bangsa adalah sebagai berikut:

1. development, yaitu pengembangan potensi peserta didik untuk menjadi pribadi berperilaku baik, ini bagi peserta didik yang telah memiliki sikap dan perilaku yang mencerminkan budaya dan karakter bangsa.

2. recovery, yaitu memperkuat kiprah pendidikan nasional untuk bertanggung jawab dalam pengembangan potensi peserta didik yang lebih bermartabat.

3. clarification, yaitu untuk menyaring budaya bangsa sendiri dan budaya bangsa lain yang tak sesuai dengan nilai-nilai budaya dan karakter bangsa yang bermartabat.

\section{b. Tujuan Pendidikan Karakter}

Pendidikan karakter dalam seting sekolah memiliki tujuan ( Kesuma,2011:25) adalah sebagai berikut :

1. Menguatkan dan mengembangkan nilai-nilai kehidupan yang dianggap penting dan perlu sehingga menjadi kepribadian/kepemilikan peserta didik yang khas sebagaimana nilai-nilai yang dikembangkan. Penguatan dan pengembangan memiliki makna bahwa pendidikan dalam seting sekolah bukanlah sekedar dogmatisasi nilai kepada peserta didik, tetapi sebuah proses yang membawa peserta didik untuk memahami dan 
merefleksi bagaimana suatu nilai menjadi penting untuk diwujudkan dalam perilaku keseharian.

2. Mengoreksi perilaku peserta didik yang tidak bersesuaian dengan nilainilai yang dikembangkan oleh sekolah.Tujuan ini memiliki makna bahwa pendidikan karakter mcmiliki sasaran untuk meluruskan berbagai perilaku anak yang negatif menjadi positif. Proses pelurusan yang dimaknai sebagai pengkoreksian perilaku dipahami sebagai proses pedagogis, bukan suatu pemaksaan atau pengkondisian yang tidak mendidik.

3. Membangun koneksi yang harmonis dengan keluarga dan masyarakat dalam memerankan tanggung jawab pendidikan karakter secara bersama-sama. Tujuan ini memiliki makna bahwa proses pendidikan karakter di sekolah harus dihubungkan dengan proses pendidikan di keluarga. Jika pendidikan karakter di sekolah hanya bertumpu pada interaksi antara peserta didik dengan guru di kelas dan sekolah, maka pencapaian berbagai karakter yang diharapkan sulit diwujudkan.

Berdasarkan pada pedoman pelaksanaan pendidikan karakter bangsa yang disusun oleh Balitbang, Kemdiknas (2011,7), tujuan pendidikan karakter bangsa sebagai berikut:

1. Mengembangkan potensi afektif peserta didik sebagai manusia dan warga negara yang memiliki nilai-nilai budaya karakter bangsa.

2. Mengembangkan kebiasaan dan perilaku peserta didik yang terpuji dan sejalan dengan nilai-nilai universal yang tradisi budaya bangsa yang religius.

3. Menanamkan jiwa kepemimipinan dan tanggung jawab peserta didik sebagai generasi penerus bangsa.

4. Mengembangkan kemampuan peserta didik menjadi manusia yang mandiri, kreatif, dan berwawasan kebangsaan.

5. Mengembangkan lingkungan kehidupan sekolah sebagai lingkungan belajar yang aman, jujur, penuh kreativitas dan persahabatan serta dengan rasa kebangsaan yang tinggi dan penuh kekuatan (dignity). 


\section{Nilai-nilai Pendidikan Karakter Bangsa}

Nilai-nilai yang dikembangkan dalam pendidikan budaya dan karakter bangsa diidentifikasi dari berbagai sumber, sehingga diperlukan kearifan berpikir dan bertindak dari kalangan pendidikan, khususnya bagaimana nilai-nilai tersebut diimplementasikan dalam proses pembelajaran di kelas.

Secara umum, sumber nilai dari pendidikan budaya dan karakter dapat diidentifikasi sebagai berikut.

a. Agama: masyarakat Indonesia adalah masyarkat beragama. Oleh kerena itu, kehidupan individu, masyarakat, dan bangsa selalu didasari pada ajaran agama dan kepercayaannya. Secara politis, kehidupan kenegaraan pun didasari pada nilai-nilai yang berasal dari agama. Atas dasar pertimbangan itu, maka nilai-nilai pendidikan budaya dan karakter bangsa harus didasarkan pada nilai-nilai dan kaidah yang berasal dari agama.

b. Pancasila: Negara Kesatuan Republik Indonesia ditegakkan atas prinsipprinsip kehidupan kebangsaan dan kenegaraan yang disebut Pancasila. Pancasila terdapat pada Pembukaan UUD 1945 dan dijabarkan lebih lanjut dalam pasal-pasal yang terdapat dalam UUD 1945. Artinya, nilai-nilai yang terkandung dalam Pancasila menjadi nilai-nilai yang mengatur kehidupan politik, hukum, ekonomi, kemasyarakatan, budaya, dan seni. Pendidikan budaya dan karakter bangsa bertujuan mempersiapkan peserta didik menjadi warga negara yang lebih baik, yaitu warga negara yang memiliki kemampuan, kemauan, dan menerapkan nilai-nilai Pancasila dalam kehidupannya sebagai warga negara.

c. Budaya: sebbagai suatu kebenaran bahwa tidak ada manusia yang hidup bermasyarkat yang tidak didasari oleh nilai-nilai budaya yang diakui masyarakat itu. Nilai-nilai budaya itu dijadikan dasar dalam pemberian makna terhadap suatu konsep dan arti dalam komunikasi antara anggota masyarakat itu. Posisi budaya yang demikian penting dalam kehidupan masyarakat mengharuskan budaya menjadi sumber nilai dalam pendidikan budaya dan karakter bangsa. 
d. Tujuan Pendidikan Nasional: sebagai rumusan kualitas yang harus dimiliki setiap warga negara Indonesia, dikembangkan oleh berbagai satuan pendidikan di berbagai jenjang dan jalur. Tujuan pendidikan nasional memuat berbagai nilai kemanusiaan yang harus dimiliki warga negara Indonesia. Oleh karena itu, tujuan pendidikan nasional adalah sumber yang paling penting dalam pengembangan pendidikan budaya dan karakter bangsa.

Berdasarkan keempat sumber nilai tersebut, dapat diidentifikasi seperangkat nilai yang relevan dikembangkan dan/ atau dikemas sebagai nilainilai dasar dari pendidikan budaya dan karakter bangsa, terdapat 18 nilai-nilai karakter yang dapat di kembangkan sebagai berikut

a. Religius : Sikap dan perilaku yang patuh dalam melaksanakan ajaran agama yang dianutnya, toleran terhadap pelaksanaan ibadah agama lain, dan hidup rukun dengan pemeluk agama lain.

b. Jujur : Perilaku yang didasarkan pada upaya menjadikan dirinya sebagai orang yang selalu dapat dipercaya dalam perkataan, tindakan, dan pekerjaan.

c. Toleransi : Sikap dan tindakan yang menghargai perbedaan agama,suku, etnis, pendapat, sikap, dan tindakan orang lain yang berbeda dari dirinya.

d. Disiplin : Tindakan yang menunjukkan perilaku tertib dan patuh pada berbagai ketentuan dan peraturan.

e. Kerja Keras : Perilaku yang menunjukkan upaya sungguh-sungguh dalam mengatasi berbagai hambatan belajar dan tugas, serta menyelesaikan tugas dengan sebaik-baiknya.

f. Kreatif : Berpikir dan melakukan sesuatu untuk menghasilkan cara atau hasil baru dari sesuatu yang telah dimiliki.

g. Mandiri : Sikap dan perilaku yang tidak mudah tergantung pada orang lain dalam menyelesaikan tugas-tugas.

h. Demokratis : Cara berfikir, bersikap, dan bertindak yang menilai terdapat persamaan hak dan kewajiban pada dirinya dan orang lain. 
i. Rasa Ingin Tahu : Sikap dan tindakan yang selalu berupaya untuk mengetahui lebih mendalam dan meluas dari sesuatu yang dipelajarinya, dilihat, dan didengar.

j. Semangat Kebangsaan : Cara berpikir, bertindak, dan berwawasan yang menempatkan kepentingan bangsa dan negara di atas kepentingan diri dan kelompoknya.

k. Cinta Tanah Air : Cara berfikir, bersikap, dan berbuat yang menunjukkan kesetiaan, kepedulian, dan penghargaan yang tinggi terhadap bahasa, lingkungan fisik, sosial, budaya, ekonomi, dan politik bangsa.

1. Menghargai Prestasi : Sikap dan tindakan yang mendorong dirinya untuk menghasilkan sesuatu yang berguna bagi masyarakat, dan mengakui, serta menghormati keberhasilan orang lain.

m. Bersahabat/Komuniktif : Tindakan yang memperlihatkan rasa senang berbicara,bergaul, dan bekerja sama dengan orang lain.

n. Cinta Damai : Sikap, perkataan, dan tindakan yang menyebabkan orang lain merasa senang dan aman atas kehadiran dirinya.

o. Gemar Membaca : Kebiasaan menyediakan waktu untuk membaca berbagai bacaan yang memberikan kebajikan bagi dirinya.

p. Peduli Lingkungan : Sikap dan tindakan yang selalu berupaya mencegah kerusakan pada lingkungan alam di sekitarnya, dan mengembangkan upaya-upaya untuk memperbaiki kerusakan alam yang sudah terjadi.

q. Peduli Sosial : Sikap dan tindakan yang selalu ingin memberi bantuan pada orang lain dan masyarakat yang membutuhkan.

r. Tanggung jawab : Sikap dan perilaku seseorang untuk melaksanakan tugas dan kewajibannya, yang seharusnya dia lakukan, terhadap diri sendiri, masyarakat, lingkungan (alam, sosial dan budaya), negara dan Tuhan Yang Maha Esa.

4. Membangun Karakter Anak dengan Budaya Kearifan Lokal dalam Proses Pembelajaran

Sejarah menunjukkan, masing-masing etnis dan suku memiliki kearifan lokal sendiri. Misalnya, suku Batak kental dengan keterbukaan, 
suku Jawa nyaris identik dengan kehalusan, suku Madura memiliki harga diri yang tinggi, dan etnis Cina terkenal dengan keuletan. Lebih dari itu, masing-masing memiliki keakraban dan keramahan dengan lingkungan alam yang mengitari mereka. Kearifan lokal itu tentu tidak muncul serta-merta, tapi berproses panjang sehingga akhirnya terbukti, bahwa hal itu mengandung kebaikan bagi kehidupan mereka. Keterujiannya dalam sisi ini membuat kearifan lokal menjadi budaya yang mentradisi, melekat kuat pada kehidupan masyarakat. Semua, terlepas dari perbedaan intensitasnya, mengeram visi terciptanya kehidupan bermartabat, sejahtera dan damai. Dalam bingkai kearifan lokal ini, masyarakat bereksistensi, dan berkoeksistensi satu dengan yang lain.

Kearifan lokal dapat didefinisikan sebagai kebijaksanaan atau nilai-nilai luhur yang terkandung dalam kekayaan-kekayaan budaya lokal berupa tradisi, petatah-petitih, kata-kata bijak dan semboyan hidup (Pikiran Rakyat, 4 Oktober 2004). Pengertian kearifan lokal dilihat dari kamus Inggris Indonesia, terdiri dari 2 kata yaitu kearifan (wisdom) dan lokal (local). Local berarti setempat dan wisdom sama dengan kebijaksanaan. Dengan kata lain maka local wisdom dapat dipahami sebagai gagasan-gagasan, nilai-nilai, pandangan-pandangan setempat (local) yang bersifat bijaksana, penuh kearifan, bernilai baik, yang tertanam dan diikuti oleh anggota masyarakatnya. Dengan demikian membangun pendidikan karakter disekolah melalui budaya kearifan lokal sangatlah tepat. Hal ini dikarenakan pendidikan yang berbasis kearifan lokal adalah pendidikan yang mengajarkan pada peserta didik untuk selalu dekat dengan situasi konkrit yang mereka hadapi sehari-hari. Model pendidikan berbasis kearifan lokal merupakan sebuah contoh pendidikan yang mempunyai relevansi tinggi bagi kecakapan pengembangan hidup, dengan berpijak pada pemberdayaan ketrampilan serta potensi lokal pada tiap-tiap daerah. Kearifan lokal milik kita sangat banyak dan beraneka ragam karena Indonesia terdiri atas bermacam-macam suku bangsa, berbicara dalam aneka bahasa daerah, serta menjalankan ritual adat 
istiadat yang berbeda-beda pula.

Masyarakat Indonesia sudah selayaknya kembali kepada jati diri mereka melalui pemaknaan kembali dan rekonstruksi nilai-nilai luhur budaya mereka. Upaya yang perlu dilakukan adalah menguak makna substantif dari budaya kearifan lokal. Contohnya adalah sikap keterbukaan dapat dikembangkan dan diaktualisasikan menjadi nilai kejujuran, toleransi, demokratis dan komunikatif. Kehalusan dapat diaktualisasikan sebagai nilai keramahtamahan, bersahabat, mudah bergaul dan bekerja sama dengan orang lain. Harga diri diletakkan dalam upaya pengembangan nilai disiplin, kerja keras, mandiri dan berprestasi. Pada saat yang sama, hasil rekonstruksi ini perlu dibumikan dan disebarluaskan ke dalam seluruh masyarakat sehingga menjadi identitas kokoh bangsa, bukan sekadar menjadi identitas suku atau masyarakat tertentu.

Persoalannya adalah bagaimana mengimplementasikan kearifan lokal untuk membangun pendidikan karakter anak dalam proses pembelajaran di sekolah? Perlu ada revitalisasi budaya lokal (kearifan lokal) yang relevan untuk membangun pendidikan karakter. Hal ini dikarenakan kearifan lokal di daerah pada gilirannya akan mampu mengantarkan siswa untuk mencintai daerahnya. Kecintaan siswa pada daerahnya akan mewujudkan ketahanan daerah. Ketahanan daerah adalah kemampuan suatu daerah yang ditunjukkan oleh kemampuan warganya untuk menata diri sesuai dengan konsep yang diyakini kebenarannya dengan jiwa yang tangguh, semangat yang tinggi, serta dengan cara memanfaatkan alam secara bijaksana.

Dalam konteks tersebut di atas, kearifan lokal menjadi sangat relevan. Anak bangsa di negeri ini sudah sewajarnya diperkenalkan dengan lingkungan daerah sekitarnya. Melalui pengenalan lingkungan yang paling kecil, maka anak-anak kita bisa mencintai desanya. Apabila mereka mencintai desanya mereka baru mau bekerja di desa dan untuk desanya. Kearifan lokal mempunyai arti sangat penting bagi anak didik kita. Dengan mempelajari kearifan lokal anak didik kita akan memahami perjuangan 
nenek moyangnya dalam berbagai kegiatan kemasyarakatan. Nilai-nilai kerja keras, pantang mundur, dan tidak kenal menyerah perlu diajarkan pada anak-anak kita. Dengan demikian, pendidikan karakter melalui kearifan lokal seharusnya mulai diperkenalkan oleh guru kepada para siswanya.

Dari berbagai literatur, ternyata kecerdasan otak yang tercermin dalam kemampuan akademik seseorang hanya akan memberikan sumbangan untuk kesuksesan hidupnya sebesar $20 \%$. Hal ini menunjukkan bahwa kecerdasan intelektual bukan satu-satunya penentu keberhasilan seseorang dalam hidupnya, tetapi masih banyak kecerdasan lain yang perlu dikembangkan secara simultan dalam proses pembelajaran di sekolah. Menurut berbagai sumber penentu terbesar dalam keberhasilan seseorang dalam hidupnya adalah sikap.Bahkan sikap ini memberikan kontribusi hampir $80 \%$ terhadap keberhasilan seseorang. Oleh karena itu pendidikan yang mengembangkan pembentukan sikap positif menjadi sangat penting. Sikap positif ini tidak lain adalah nilai-nilai karakter yang sesuai dengan falsafah dan pandangan hidup bangsa.

Semua guru yang mengajar dan mendidik di sekolah, diharapkan mendidik dengan hati dalam rangka membentuk sikap positif siswanya. Guru dilatih untuk mendesain sendiri rancangan pembelajarannya sehingga apa yang terpikir secara baik oleh guru dapat segera diajar-latihkan kepada siswa agar siswa memiliki dasar-dasar sikap positif untuk melanjutkan pendidikannya. Beberapa kalimat bijak yang berbasis kearifan lokal dapat digunakan sebagai dasar pembangunan sikap positif pendidikan karakter. Kata-kata bijak yang merupakan bagian dari budaya kearifan lokal tersebut, antara lain sebagai berikut

a. Rame ing Gawe, Sepi ing Pamrih

Kata-kata bijak ini memiliki arti yang mengandung sebuah perintah atau ajakan. Yaitu ajakan agar seseorang senantiasa berbuat baik kepada siapapun, tanpa ada pilih kasih. Setelah berbuat baik seseorang diajak untuk tidak mengharapkan imbalan (pamrih) sedikitpun dari apa yang 
telah ia perbuat. Kata bijak ini juga mengajarkan kepada kita untuk selalu mengutamakan bekerja, bekerja, dan bekerja dan tidak terlalu berharap akan pujian. Dari ungkapan kata tersebut bisa dibayangkan, apa yang akan terjadi di Jawa khususnya jika sebagian besar masyarakatnya bisa memaknai dan mengaplikasikan ungkapan tersebut dalam kehidupan sehari-hari? Pertanyaan berikutnya adalah apa yang akan terjadi di negara Indonesia, jika semua pemimpin dan pejabatnya yang berasal dari suku Jawa bisa memaknai dan mengaplikasikannya dalam aktifitas kepemerintahannya? Dari ungkapan tersebut sekarang bisa terlihat bahwa sebenarnya nilai dari sebuah budaya lokal adalah sesuatu yang hebat.

b. Ing Ngarsa Sung Tulada, ing Madya Mangun Karsa, Tutwuri Handayani

Kata-kata bijak ini adalah sebuah ajakan agar seseorang bisa menyelesaikan dengan kondisi dan posisinya masing- masing. Apabila ia menjadi seorang pimpinan maka ia mampu menjadi suri teladan yang baik, apabila ia berposisi menjadi seorang penggerak (menteri/ pejabat tinggi) maka ia mampu memelihara kualitas kinerjanya, dan apabila ia menjadi seorang pejabat/ pegawai/ aparat perintah dan sebagainya maka ia sanggup menjaga dedikasi (memberi kekuatan/ dukungan).

\section{c. Becik Ketitik Ala Ketara}

Kata-kata bijak ini memberi inspirasi kepada siapa saja, bahwa pada akhirnya seseorang akan menuai apa yang telah ditanamnya. Dengan begitu tidak ada alasan bagi seseorang untuk melakukan suatu perbuatan yang buruk, karena pada akhirnya sudah pasti orang tersebut tidak akan bisa mendapatkan kebahagiaan.

\section{d. Manungso bakal ngundhuh wohing pakarti}

Maknanya bahwa sebenarnya manusia hanya akan memetik atau memanen apa yang dilakukan selama hidupnya. Oleh karena itu dalam proses pembelajaran harus selalu diingatkan dan dilatihkan bahwa setiap orang selama hidupnya akan merasakan apa saja yang telah dilakukannya. Apabila yang dilakukan lebih banyak kebaikan, maka yang akan diperolehnya adalah kebaikan dan sebaliknya apabila yang 
dilakukan perbuatan yang kurang baik, maka sepanjang hidupnya juga akan memetik hal-hal yang kurang menyenangkan.

e. Ajining diri soko lathi

Maksudnya harga diri seseorang tergantung dari ucapannya. Dalam konteks ini guru dan siswa harus selalu berlatih, berbicara dengan kata-kata yang baik, sopan dan jujur. Karena hal tersebut akan mencerminkan harga diri dan kehormatan seseorang. Orang lain akan menghormati kita karena tutur bahasa kita. Kata bijak ini akan dapat mengembangkan nilai-nilai karakter kejujuran dan toleransi.

\section{f. Rukun agawe santoso}

Ungkapan ini mempunyai makna bahwa dalam hidup baik itu dalam lingkungan keluarga, masyarakat, sekolah, berbangsa dan bernegara apabila dilandasi kerukuan menjadi kokoh dan kuat. Sebaliknya apabila dalam perjalan hidup ini tidak mau bersatu dengan orang lain, tidak peduli, individualistis, tidak bersahabat, maka kehidupan terasa sulit dan apabila ada permasalahan akan cepat putus asa. Kata bijak ini dapat mengembangkan nilai-nilai karakter bersahabat komunikatif,yang memperlihatkan rasa senang bergaul dan bekerjasama dengan orang lain, punya kepedulian sosial, yaitu sikap yang selalu igin memberi bantuan pada orang lain dan masyarakat yang membutuhkan.

\section{g. Mikul dhuwur mendem jero.}

Kata bijak ini mempunyai makna bahwa kita harus bisa menghargai setinggi mungkin jasa orang tua kita atau para pendahulu kita dan kita harus dapat menutup rapat-rapat kesalahan atau dosa orang tua atau pendahulu kita.

\section{h. Bapantang kusuik nan tak salasai}

Kata bijak tersebut mempunyai makna ketika seseorang atau sekelompok orang sudah memulai suatu pekerjaan atau kegiatan, apapun masalah atau hambatannya harus dapat diselesaikan, baik secara sendirisendiri ataupun bersama-sama. Nilai karakter yang dapat dikembangkan 
dari kata bijak tersebut adalah kerja keras, tanggungjawab terhadap tugas dan menghargai prestasi.

i. Sekali langkah diayun, pantang untuk kembali.

Makna dari kata bijak tersebut adalah, apabila kita sudah memulai kegiatan atau program harus dikerjakan sampai selesai, apapun hasilnya. Hal ini memberikan implikasi bahwa seseorang kalau sudah mulai mengerjakan sesuatu harus terus bekerja dan tak akan pernah berhenti sebelum sampai ke tujuan. Nilai karakter yang dapat dikembangkan dari kata bijak ini adalah kedisiplinan, rasa tangggungjawab, dan kerja keras.

Makna dari kata bijak ini dapat digunakan untuk mengingatkan dan melatih siswa agar selalu menjadi manusia yang tangguh. Guru dapat menjelaskan tipe-tipe manusia dalam mewujudkan cita-citanya. Ada orang yang mudah menyerah ketika baru mulai menghadapi kesulitan dalam berusaha (quitters). Kebanyakan orang akan berhenti berusaha sebelum tenaga dan batas kemampuan mereka benar-benar teruji (campers). Sebagian lagi terus berusaha apapun rintangannya sampai berhasil mencapai tujuan (climbers).(Bejo Sujanto,2012:4)

Dengan memberikan ilustrasi tentang tipe-tipe manusia tersebut, siswa akan tahu bahwa ada manusia yang mudah menyerah menghadapi tantangan, akibatnya mereka tidak akan mampu meraih impian hidupnnya karena memilih jalan yang dianggap mudah dan mengabaikan potensinya. Ada juga tipe manusia yang menyerah sebelum usahanya maksimal, mereka hanya mengisi hidupnya yang dianggap nyaman dan mengorbankan hal-hal yang mungkin masih bisa diraihnya. Selanjutnya tipe manusia yang tangguh dan tidak mudah menyerah, dan mereka inilah yang akan berhasil mewujudkan puncak cita-cita atau impiannya.

\section{j. Kehidupan yang besar selalu dimulai dengan impian-impian besar}

Makna dari kata bijak tersebut adalah dalam hidup ini apabila kita ingin mencapai kesuksesan maka mulailah dengan impian-impian besar mengenai apa yang kita cita-citakan. Impian akan memberikan motivasi kepada seseorang untuk berusaha mewujudkannya. Nilai karakter yang 
dapat dikembangkan dari kata bijak ini adalah kerja keras, disiplin, rasa ingin tahu, mandiri, dan menghargai prestasi demi tercapainya impian besarnya.

Dalam proses pembelajaran guru harus dapat memotivasi dan meyakinkan kepada siswa, bahwa setiap manusia itu di samping mempunyai kekurangan juga mempunyai kelebihan-kelebihan. Hal tersebut sangat penting dijelaskan kepada siswa, agar siswa yang merasa memiliki kekurangan tidak berputus asa akibat kekurangannya tersebut, karena setiap orang juga mempunyai kelebihan dan harus yakin bahwa dengan kelebihannya tersebut mereka pasti dapat berhasil disetiap apa yang diusahakan. Oleh karena itu, kepada siswa perlu dijelaskan juga bahwa, hidup seperti kunci kombinasi, tugas dari kita adalah menemukan angka-angka yang tepat dengan urutan yang tepat, sehingga kita dapat membuka pintu kesuksesan. Tidak ada resep khusus yang membuat orang sukses, kecuali berusaha maksimal, yang berbentuk kerja keras, belajar rajin, punya rasa ingin tahu yang tinggi, disiplin, dan ulet. Harta yang paling berharga adalah keinginan kita untuk mau berusaha pantang menyerah.

Tentu masih banyak lagi kata-kata bijak yang merupakan budaya kearifan lokal yang dapat digunakan untuk mengembangkan karakter anak dalam proses pembelajaran di sekolah. Hal yang paling utama adalah kesungguhan kita sebagai pendidik untuk selalu mendidik dengan hati. Mendidik dengan hati akan mengutamakan pembentukan sikap positif seperti; jujur, toleran, amanah, saling asah dan asuh, optimistis, percaya diri, ulet, tangguh dan lain sebagainya.

\section{Penutup}

Berdasarkan uraian di atas dapat disimpulkan bahwa :

1. Membangun pendidikan karakter di sekolah melalui budaya kearifan lokal mengandung nilai-nilai yang relevan dan berguna bagi pendidikan. Oleh karena itu pendidikan karakter berbasis kearifan lokal dapat dilakukan dengan merevitalisasi budaya lokal. Untuk mewujudkan 
pendidikan karakter disekolah berbasis kearifan lokal memerlukan adanya pengertian, pemahaman, kesadaran, kerja sama, dan partisipasi seluruh elemen warga belajar.

2. Membangun karakter siswa dapat dilakukan sepanjang proses pembelajaran berlangsung. Dalam setiap proses pembelajaran selalu dapat kita selipkan muatan nilai-nilai kejujuran, keberanian, ketekunan dan keuletan, sikap percaya diri, rajin belajar dan bekerja, hormat kepada orang tua dan guru, menghormati dan menyayangi sesama, hidup tangguh tidak kenal kata menyerah dan sikap positif yang lain. Beberapa kata bijak yang merupakan bagian dari budaya kearifan lokal dapat digunakan sebagai pijakan dalam mengembangkan nilai-nilai karakter dalam proses pembelajaran. Kata-kata bijak tersebut dapat digunakan untuk memotivasi siswa dalam membangun sikap positif tersebut.

\section{Daftar Pustaka}

Arifin. 2001. Jalan Menuju Ma 'ratullah dengan Tahapan . Surabaya:Terbit Terang.

Bedjo Sujanto. 2012. Membangun Karakter Bangsa Melalui Penerapan M anajemen Berbasis Sekolah. Makalah disampaikan dalam KONASPI VII. Yogyakarta, 2012.

Danah Zohar dan Marshall, Ian. SQ, Memanfaatkan Kecerdasan Spiritual Dalam Berpikir Integralistik dan Holistik untuk Memaknai Kehidupan, Diterjemahkan Oleh Rahmani Astuti. Bandung: Mizan, 2001.

Dasim Budimansyah (Editor). 2006. Pendidikan Nilai Moral dalam Dimensi Pendidikan Kewarganegaraan. Bandung: Laboratorium Pendidikan Kewarganegaraan, FPIS- UPI.

Dharma Kesuma. 2011. Pendidikan Karakter - Kajian Teori dan Praktek di Sekolah. Bandung: PT Remaja Rosdakarya Offset.

Direktorat Jenderal Kesatuan Bangsa dan Politik Departemen Dalam Negeri. 2007. Peraturan Menteri Dalam Negeri Nomor 39 Tahun 2007 tentang Pedoman Fasilitasi Organisasi Kemasyarakatan Bidang Kebudayaan, Keraton, dan Lembaga Adat dalam Pelestarian dan Pengembangan Budaya Daerah. 
Djoko Dwiyanto dan Gatot Saksono. 2012. Pendidikan Karakter Berbasis Pancasila, Negara Pancasila; A gama atau Sekuler; Sosiolis atau Kapitalis. Yogyakarta: Ampera Utama.

Elizabeth B. Hurlock. 1974. Personality Development. New York: McGraw-Hill Book Company.

Hasan Alwi, dkk. 2001. Kamus Besar Bahasa Indonesia-Edisi Ketiga. Jakarta:Ba1ai Pustaka.

Kemdiknas.2011.Panduan Pelaksanaan Pendidikan Karakter . Jakarta : Badan Penelitian dan Pengembangan Pusat .

Lawrence A. Blum, 2001. "Antirasisme, Multikulturalisme, dan Komunitas Antar-Ras" Tiga Nilai yang Bersifat Mendidik bagi Sebuah Masyarakat Multikultural", dalam L. May, S. Collins-Chobanian, dan K. Wong, editor, Etika Terapan I: Sebuah Pendekatan Multikultural. Yogyakarta: Tiara Wacana.

Mohammad Fakry Gaffar. 2011. Pendidikan Karakter Berbasis Islam (Disampaikan pada Workshop Pendidikan Karakter Berbasis Agama, 8-10 April 2010 di Yogyakarta).

Mitra fm.Kecerdasan Spiritual Menentukan Jati Diri.Diakses pada tanggal 12 Januari 2010 dari http://mitrafm.com/blog/2008/12/15/kecerdasan-spiritual$\underline{\text { menentukan- jati-diri }}$

Nancy A Wood.What is Character? Diakses pada Tanggal 11 January 2010 dari http://ezinearticles.com.

Ratna Megawangi. 2004. Pendidikan Karakter: Solusi yang Tepat untuk Membangun Bangsa. Bogor: Indonesia Heritage Foundation.

Rohmat Mulyana. 2011. Mengartikulasikan Pendidikan Nilai. Bandung: Penerbit Alfabeta.

Sunaryo Kartadinata.Pendidikan Belum Membangun Karakter Bangsa.Kompas 7 Mei 2009.Diakses pada tanggal 12 Januari 2010 dari http://www.schoolfor-champions.com.

Umar Tirta Rahardja. 2005. Pengantar Pendidikan. Jakarta: Diterbitkan atas kerjasama Pusat Keguruan Depdiknas dengan Penerbit Rineka Cipta.

Undang_-Undang Nomor 20 Yahun 2003 tentang Sistern Pendidikan Nasional. 